\title{
Academic Performance Analysis of Information Technology Students in Higher Education Institutions
}

\author{
Deepti Sharma, Deepshikha Aggarwal, Disha Grover
}

\begin{abstract}
This research is conducted to analyse the factors that may affect the academic performance of students in the MCA (Masters in Computer Application) course in Delhi, India. MCA is a three year post graduate programme in Computer Application. This work will help to better understand the factors that commonly affect the performance of students in academics and also will contribute to the pedagogy development of educational institutes. The seven factors that have been considered for the analysis arethe Faculty, time management, interest of students,placements, difficulty of course, sources of study and extra efforts by students. The hypothesis has been developed to establish the relationship between the independent variables which are the seven factors and the dependent variable which is the academic performance. The research is conducted on the data collected from the students through questionnaire and we have chosen to use convenience sampling to conduct this study. The data thus collected is tested using the multiple linear regression model as multiple factors have been considered. The result of the analysis indicate that the Faculty, time management, interest of students, placements, difficulty of course, sources of study and extra efforts by students have a positive effect on the academic performance of the students. Measuring the academic performance of the student is a difficult task as it cannot be measured quantitatively. In most of the cases the student performances are also affected by various environmental, socio-economic and psychological factors. These factors also need to be considered while assessing the academic performance of the students. Still the factors incorporated in this study give a considerable result regarding their influence on the academic performance of the students. The results of the research can be useful for various academic institutions to formulate the educational pedagogy that can accommodate the most influential factors for better academic performance of the students.
\end{abstract}

Keywords: Data analysis, Regression, Student performance Analysis, Higher education, Technical education, Data Science

\section{INTRODUCTION}

Education plays a pre-eminent role in one's career and for the production of human capital for any country. Education impacts the mind, soul and character of an

Revised Manuscript Received on June 15, 2019.

Deepti Sharma, Department of Information Technology, Jagan Institute of Management Studies, Rohini, Delhi, India.

Deepshikha Aggarwal, Department of Information Technology, Jagan Institute of Management Studies, Rohini, Delhi, India.

Disha Grover, Department of Information Technology, Jagan Institute of Management Studies, Rohini, Delhi, India. individual and the worth of any college or institute is with the students associated[1].

Students are the asset to any institute, their academic performance largely impacts society's growth. Quality of their performance is always the utmost priority of the educators. The performance is dependent on various factors like social, economic and personal, peer and many more factors[2]. The student performance is strongly dependent on them but the factors differ from student to student and nation to nation. The conduct of the students can be measured using various ways such as CGPA, GPA and some other test results[3][4].

Moreover, in today's time of technological revolution, the education is observed as the initial step for the growth of each and every human activity. This somehow relates to the person's well-being and their better life style[5]. The researchers, teachers, instructors have always been interested in inquiring variables/ factors that plays a vital role in the students' performance.

Nowadays, many students are focussed on cheating rather than self-learning and exploring various text or reference books which in turn lead to graduate but unskilled professionals. These students are graduating only on paper that is they do not have any knowledge of the domain or profession they will be a part of.

\section{LITERATURE REVIEW}

Various researches have been made to analyse the conduct of the learners. Most of the studies involved the GPA (Grade Point Average) as a popular method to calculate the result of the students.

Kochhar postulated that correct direction is required to aid students in problems such as minimal correlation among skill set and output, improper study practices, imperfect learning methods[6]. Abdullah says researchers and surveys have revealed that result of the students is dependent upon various factors such as facilities they are getting, age and sex differences. The most crucial factor which impacts the student's performance in a positive way is their proficiency in English[7]. William \& Burden discovered that language classrooms raises confidence in students for communication, to attempt advanced methods to convey meanings and to learn from positive and negative outcomes [8].

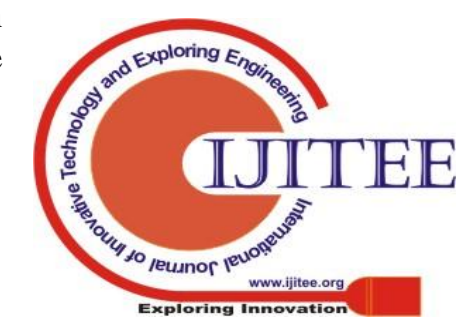


Noble explained that the student's background like family income, parent's directions, and count of unavoidable circumstances at home and level of education of parents are somehow linked with their scores. Hussain says correct instructions forms a vital component via which students gets to know how to lead his approach to learn and decide the schedule of study which directly corresponds to academic accomplishment. Students who get appropriate guidance from their guardians do well in the examinations and are influenced to study better, revealed the studies. [9] Hanushek found that the peer/ friends have more influence on each other rather than their family. Help from friends play a positive role in student's result. With each other's help they might increase their skill set. Peer teaching also encourages student's participation[10][11]. Karemera says the performance of the students is majorly impacted by satisfaction from the surrounded environment, the lab and the library facility in the institute[12].

\section{ANALYSIS OF FACTORS AFFECTING THE ACADEMIC PERFORMANCE OF STUDENTS}

The factors affecting the academic performance of students in the MCA course are analysed by using the different questions that were prepared on the basis of these factors. The questionnaire was distributed online to $50 \mathrm{MCA}$ students where they were asked to fill the demographic data and the analysis of factors was done on the basis of questions where the students were asked to respond on the likert scale. The following factors were considered for the study:

\begin{tabular}{|c|}
\hline $\begin{array}{l}\text { Faculty } \\
\text { Faculty plays a very important role in shaping the } \\
\text { future of students. The faculty not only teaches } \\
\text { but also act as a mentor and guide to the students. }\end{array}$ \\
\hline Questions for Role of faculty \\
\hline I discussed $n$ \\
\hline $\begin{array}{l}\text { If I don't understand a concept, I ask the faculty } \\
\text { for clarification. }\end{array}$ \\
\hline $\begin{array}{l}\text { The success of my courses depends more on the } \\
\text { faculty than my own effort. }\end{array}$ \\
\hline $\begin{array}{l}\text { Placement } \\
\text { The common motivation for study for the } \\
\text { students is getting a job so placement plays an } \\
\text { important role in the academic performance of } \\
\text { students. }\end{array}$ \\
\hline Questions related to Placement \\
\hline $\begin{array}{l}\text { I believe that what I am learning in my studies } \\
\text { will be useful in my future. }\end{array}$ \\
\hline The main goal for me is to get placement. \\
\hline $\begin{array}{l}\text { I find myself more interested in subjects which } \\
\text { directly help in placement. }\end{array}$ \\
\hline
\end{tabular}

\section{Interest}

The students perform better in a course if it interests them. Therefore the interest of students is taken into consideration.

Questions for Student Interest

If a subject does not interest me, I often miss important points in class.

Good course material improves my interest in the subject.

If a subject interests me, I look for ways that will help me understand it better.

\section{Time Management}

Time management plays an important role in the success of student academic performance.

Questions on Time Management

I do not get adequate time to spend on my studies.

I have a fixed time slot for my studies.

I feel bored when studying and quit before I finish what I plan to study.

\section{Difficulty}

The difficulty level of different subjects in the course also effect the academic performance of the students.

Questions on Difficulty of course

I find certain subjects of the MCA course difficult.

If I find a subject is , I usually give up or focus on the easy parts.

I ask students in my class for help in my studies.

\section{Sources of study}

The different sources of study like the class notes, study ,material provided, Internet resources, etc. also effect the academic performance of the students.

Questions on Sources of study

I prefer to use internet rather than text books.

I read most of the suggested text books for the course.

I restrict myself to study only the content taught in class.

\section{Extra Effort}

The students need to put in extra efforts apart from the content delivered in the classes for their studies in order to achieve better results. Therefore, we have also taken it into consideration as a factor affecting the academic performance.

Questions on Extra Efforts by students

I try to put extra efforts for my studies even if I don't like what I am studying.

I try to contribute to class discussion as much as possible.

I want to do well in my studies to prove my ability to my family, friends and othe

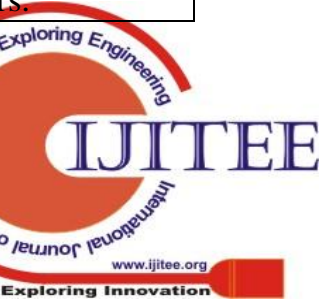




\section{International Journal of Innovative Technology and Exploring Engineering (IJITEE) \\ ISSN: 2278-3075, Volume-8, Issue-9S, July 2019}

\section{THEORETICAL FRAMEWORK}

This study considers the factors affecting the academic performance of the students and performs an analysis on these factors to establish the relationship between independent and dependent variables. The factors were decided after a discussion with faculty members and student representatives. There were many points that were discussed related to students' academic performance and many factors were identified for the same but the selected seven factors were considered to be most important in affecting the academic performance of the students. Figure 1 depicts the factors chosen for the research.

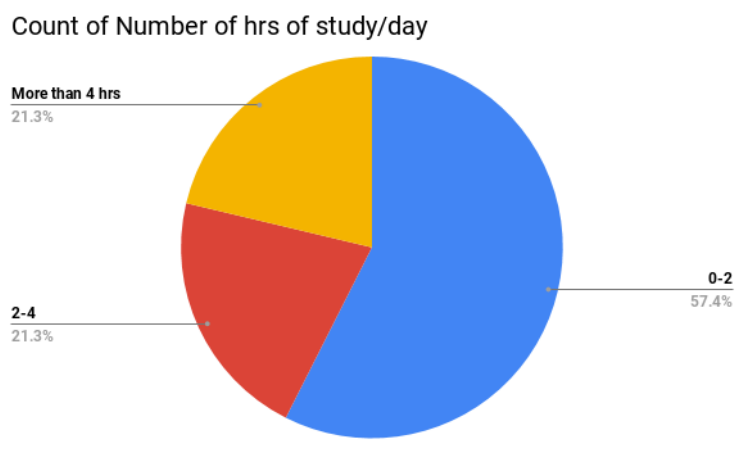

Fig 3:. Count of Number of hours of Study/day

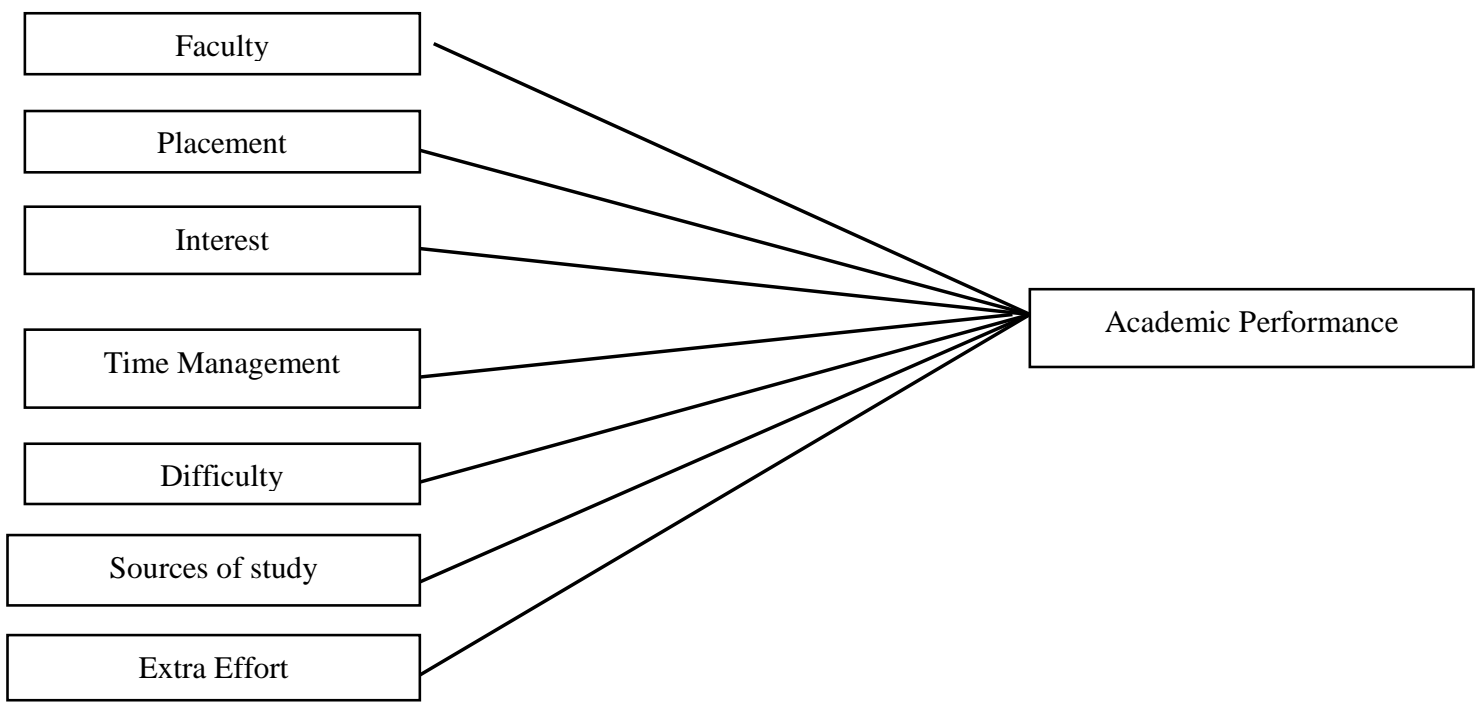

Fig 1: Theoretical Framework

The following figures demonstrate the data demographics. Figure 2 represents the percentage of male and female students. Figure 3 represents the count of number of hours of study as indicated by the sample group of students. Figure 4 represents the marks obtained by the students. This data has been collected for the purpose of conducting this research.

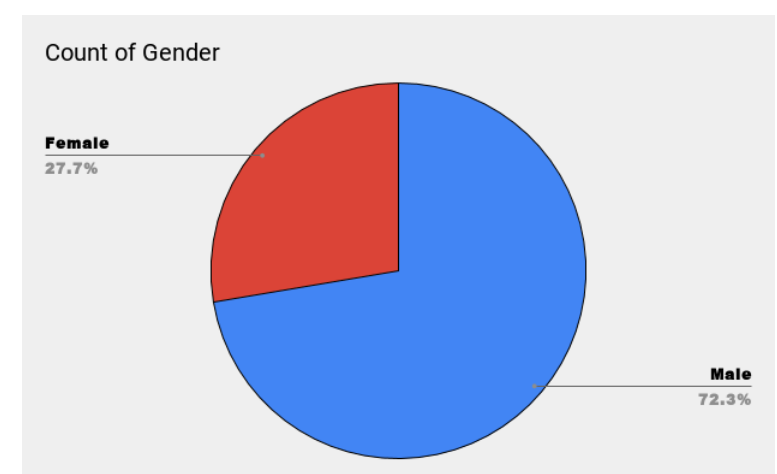

Fig 2:. Count of Gender

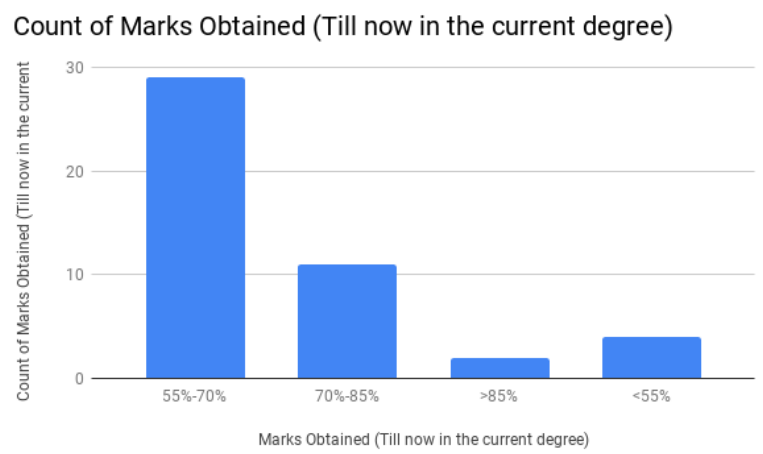

Fig 4: Count of Marks Obtained

Rating of the most important factors for the academic performance was done by the students on the scale of 1 to 7 (7 being most important). The factors considered for the rating were Faculty as indicated in Figure 5, Placements as indicated in Figure 6, Time Management as indicated in 
Figure 7 and Interest in course as indicated Figure 8. The ratings given by the students clearly indicate that these factors are considered very important by the students in respect of their academic performance.

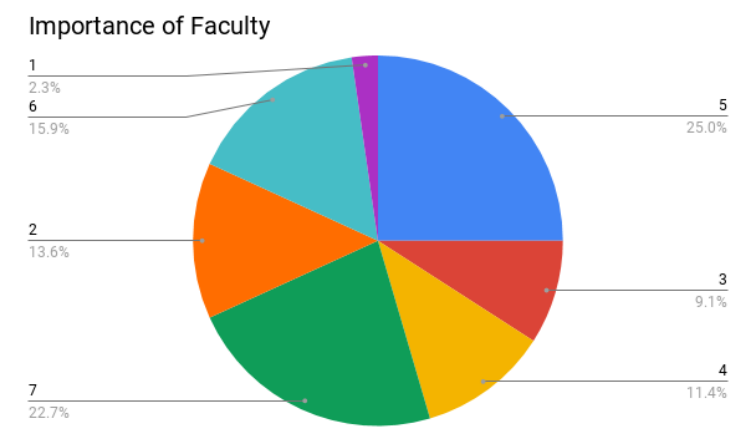

Fig 5: Importance of Faculty

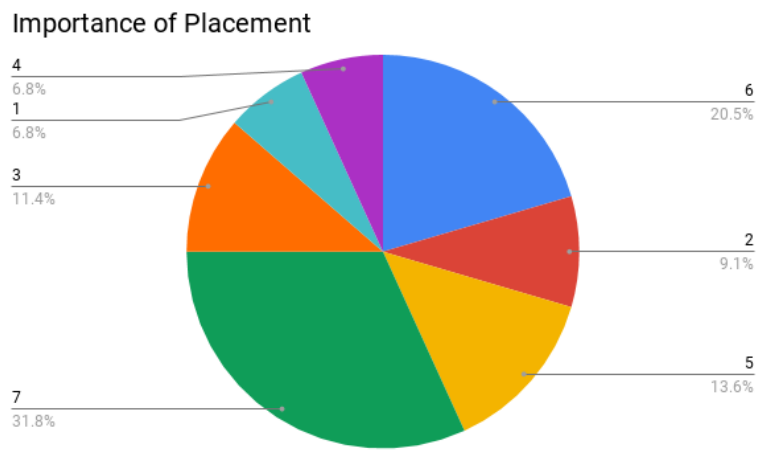

Fig 6: Importance of Placements

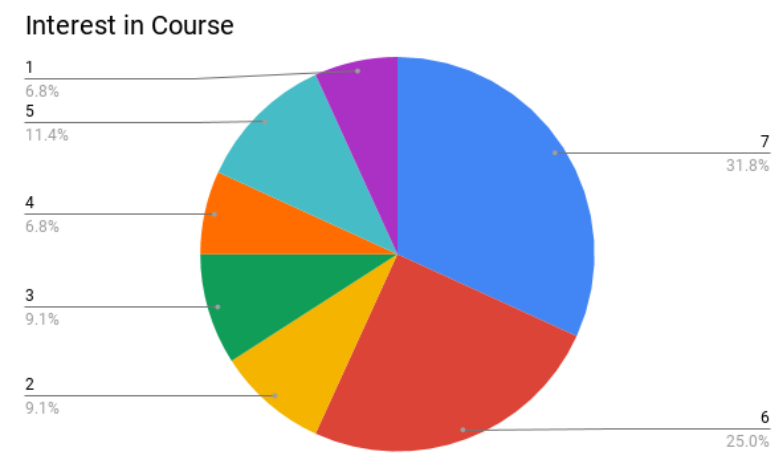

Fig 7:. Interest in course

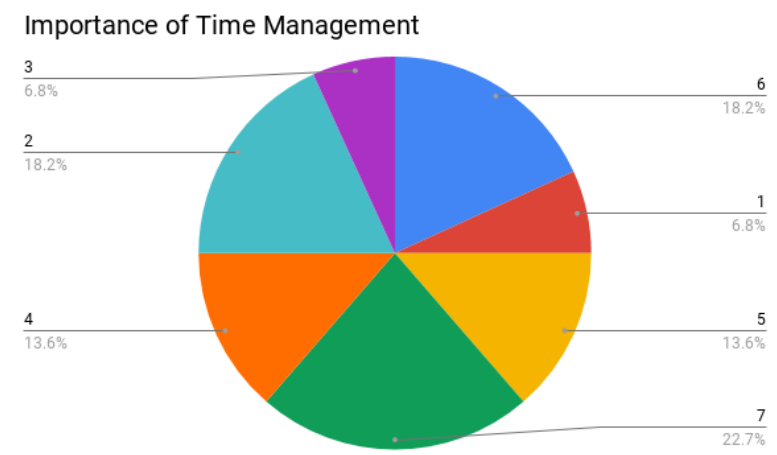

Fig 8.: Time Management

\section{METHODOLOGY}

Data and variables, measures, model and statistical tools used for the study are described in this section.

A) Data and the variables

Data is collected through primary survey. Questionnaire is used for the primary survey. The questionnaire was sent through e-mail, Facebook or WhatsApp to around 60 people. Out of those, 48 people responded. After collecting the results, the author has done the data analysis using statistical technique of multiple regression analysis.

B) Measures

The range of presence for all variables in this paper is calculated on likert scale. The likert scale has a range from, strongly agree to strongly disagree. A numerical scale conversion has been used to convert questionnaire answers ranging from " 1 " to "strongly disagree" and " 5 " to "strongly agree".

Statistical Tools

Various statistical tools like standard deviation, mean and linear and multiple regression are used for this study.

\section{RESULT AND DISCUSSION}

Outcomes of the research are discussed in this section.

\section{A) Graphic Analysis}

This section represents standard deviations and means for the independent variables, faculty, placement, interest, time management, difficulty, sources and efforts and dependent variable, academic performance

\section{B) Regression Analysis}

It includes coefficient values, Summary results of model and ANOVA Test results.

Model Summary Model summary is shown below in Table. Value of RSquare is 0.745130034 shows that $74 \%$ variation in academic performance is due to the independent variables faculty, placement, interest, time management, difficulty, sources and efforts and dependent variable academic performance.
Table I: Regression Analysis

\begin{tabular}{|l|c|}
\hline \multicolumn{2}{|c|}{ Regression Statistics } \\
\hline Multiple R & 0.863209148 \\
\hline R Square & 0.745130034 \\
\hline Adjusted R Square & 0.70052779 \\
\hline
\end{tabular}




\begin{tabular}{|l|c|} 
Standard Error & 0.337876465 \\
\hline Observations & 48 \\
\hline
\end{tabular}

Predictors: (Constant), faculty, placement, interest, time management, difficulty, sources and efforts
Analysis of variance (ANOVA)is also a part of regression analysis which shows that the overall model is significant or not. If we refer to the last column of table, the value of significance $F$ tells that the regression model is highly significant to fit the da

Table II:ANOVA Analysis

\begin{tabular}{|l|c|l|l|l|l|}
\hline \multicolumn{7}{|c|}{ ANOVA } \\
\hline & $d f$ & $S S$ & $M S$ & $F$ & Significance \\
\hline & 7 & 13.35024644 & 1.907178 & 16.70611 & 0.00004 \\
\hline Regression & 70 & 4.566420226 & 0.114161 & & \\
\hline Residual & 47 & 17.91666667 & & & \\
\hline Total & 47 & & \\
\hline
\end{tabular}

Table III: Results

\begin{tabular}{|c|c|c|c|c|c|c|c|c|}
\hline & Coefficients & $\begin{array}{l}\text { Standard } \\
\text { Error }\end{array}$ & $t$ Stat & P-value & Lower $95 \%$ & $\begin{array}{l}\text { Upper } \\
95 \%\end{array}$ & $\begin{array}{l}\text { Lower } \\
95.0 \% \\
\end{array}$ & Upper $95.0 \%$ \\
\hline Intercept & 4.068186614 & 0.554680495 & 7.334288 & $6.45 \mathrm{E}-09$ & 2.947135517 & 5.189238 & 2.947136 & 5.189238 \\
\hline $\begin{array}{l}\mathrm{X} \\
\text { Variable } \\
1\end{array}$ & $\begin{array}{l}- \\
0.158309137\end{array}$ & 0.085267761 & -1.85661 & 0.070742 & -0.33064171 & 0.014023 & -0.33064 & 0.014023 \\
\hline $\begin{array}{l}\text { X } \\
\text { Variable } \\
2 \\
\end{array}$ & 0.113585269 & 0.106089099 & 1.070659 & 0.290741 & $\begin{array}{l}- \\
0.100828799\end{array}$ & 0.327999 & -0.10083 & 0.327999 \\
\hline $\begin{array}{l}\mathrm{X} \\
\text { Variable } \\
3 \\
\end{array}$ & $\begin{array}{l}- \\
0.678035749\end{array}$ & 0.109170764 & -6.21078 & $2.39 \mathrm{E}-07$ & $\begin{array}{l}\overline{0} \\
0.898678094\end{array}$ & -0.45739 & -0.89868 & -0.45739 \\
\hline $\begin{array}{l}\mathrm{X} \\
\text { Variable } \\
4 \\
\end{array}$ & $\begin{array}{l}- \\
0.010677756\end{array}$ & 0.09156218 & -0.11662 & 0.907747 & $\begin{array}{l}- \\
0.195731824\end{array}$ & 0.174376 & -0.19573 & 0.174376 \\
\hline $\begin{array}{l}\text { X } \\
\text { Variable } \\
5\end{array}$ & 0.014055905 & 0.100754974 & 0.139506 & 0.889751 & $\begin{array}{l}- \\
0.189577493\end{array}$ & 0.217689 & -0.18958 & 0.217689 \\
\hline $\begin{array}{l}\mathrm{X} \\
\text { Variable } \\
6\end{array}$ & 0.631975611 & 0.201366269 & 3.138438 & 0.003186 & 0.2249992 & 1.038952 & 0.224999 & 1.038952 \\
\hline $\begin{array}{l}\text { X } \\
\text { Variable } \\
7\end{array}$ & $\begin{array}{l}- \\
0.282341179\end{array}$ & 0.106393165 & -2.65375 & 0.011365 & $\begin{array}{l}- \\
0.497369787\end{array}$ & -0.06731 & -0.49737 & -0.06731 \\
\hline
\end{tabular}

have been used to for the explanation of factors based on data collected. The most important results derived from the research are that about $74 \%$ of the academic performance of students in higher education is influenced by the factors considered in this study that is faculty, placement, interest, time management, difficulty, sources and efforts. The values of f-test and coefficients are also validated

Academic performance of students is affected by multiple factors including faculty, placement, interest, time management, difficulty, sources and efforts. In this research we have analysed these factors and their effect on academic performance of students. For the purpose of conducting the research, the primary data was collected and various statistical tools have been applied for deriving the results: Yarious graphs and figures DOI: 10.35940/ijitee.I1 125.0789S19

and proved that they fit in the data collected.

Published By:

Blue Eyes Intelligence Engineering

\& Sciences Publication 


\section{REFERENCES}

1 S. N. K. Irfan Mushtaq, "Factors Affecting Students' Academic," Global Journal of Management and Business Research, vol. 12, no. 9, June 2012 pp. 16-22.

2 N S. Nisha Arora, "Factors Affecting the Academic Performance of College Students," i-manager's Journal of Educational Technology, 2017 pp. 47-53.

3 G M. Hiluf Reda, "Investigating the Causes of Students' Less Academic Performance in Engineering College of Debre Berhan University," American Journal of Theoretical and Applied Statistics, vol. 7, no. 3, 2018 pp. 126-131.

4 S. R. N. Syed Tahir Hijazi, "Factors Affecting Students' Performance," Bangladesh e-Journal of Sociology, vol 3, no. 1, 2006.

5 S. N. K. Irfan Mushtaq, "Factors Affecting Students' Academic," Global Journal of Management and Business Research, vol. 12, no. 9, 2012.

6 S. K. Kochhar, Educational and Vocational Guidance in Secondary Schools, New Delhi: Sterling Publishers Private Limited, 2000.

7 A. AL-Mutairi, Factors affecting business students' performance in Arab Open University: The case of Kuwait, vol. 6, 2011, pp. 146-155

8 A H. Ch., "Effect of Guidance Services on Study Attitudes, Study Habits and Academic Achievement of Secondary School Students," Bulletin of Education \& Research, vol. 28, no. 1, 2006, pp. 35-54.

9 C. M. J. S. P. H. a. H. M. Javed Hussain, "Ethnic minority graduate entrepreneurs in the UK," vol. 21, no 6, 2007, pp. 455-463.

10 J. F. K. J. M. M. S. G. R. Eric A. Hanushek, "Does Peer Ability Affect Student Achievement," Journal of Applied Econometrics, vol. 18 , no. 5, 2003, pp. 527544.

11 S. D. S.P Rao, "Peer instruction improves performance on quizzes," Advances in Physiology Education, vol. 24, no. 1, 2000, pp. 51-55.

12 D karemera, "The Effects of academic environment and background characteristics on students' satisfaction and performance: The Case of South Carolina State University's School of Business," College Student Journal, vol. 37, no. 2, 2003, pp. 298-311.

\section{AUTHORS PROFILE}

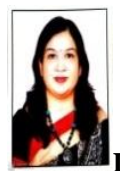

r. Deepti Sharma is an Associate Professor in Department of Information Technology at Jagan Institute of Management Studies, Rohini, Delhi. She has done her Phd from IGNOU in the area of Cluster Computing. She has more than 13 years of rich teaching experience. Her research areas include Distributed Systems, Big Data Analytics, Data Sciences and Mobile Banking. She has published more than 20 research papers in various International conferences and journals.

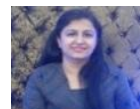

Dr Deepshikha Aggarwal is a highly accomplished faculty and researcher with extensive experience of over 18 years in academia. She has done B.E., M. Tech and $\mathrm{PhD}$ in Computer Science. She has written several research papers for various National and International journals and presented papers at different seminars and conferences. Her research interests include Social Network Analysis, Data quality, Computer networks, cyber security, E-learning and Data Science.

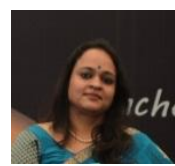

Ms. Disha Grover is associated with Jagan Institute of management Studies, Rohini affiliated to Guru Gobind Singh Indraprastha University, from past 10 years. Currently, she is working as an Assistant Professor in the field of Information Technology. She is pursuing her $\mathrm{PhD}$. from Jagannath University, Jaipur in Cloud Computing. She has various research papers published in national and international journals to add to her name. She also has keen interest in the field of Databases and Robotics. 